\title{
O SERVIÇO NOTARIAL E DE REGISTRO: DA JUDICIALIZAÇÃO À COMPOSIÇÃO DE CONFLITOS COMO UM CONTRAPONTO À BUROCRACIA ESTATAL
}

\author{
NOTARY AND REGISTRY SERVICES: FROM JURISTICTION TO THE \\ FORMULATION OF CONFLICTS AS A COUNTERPOINT TO STATE \\ BUREAUCRACY
}

\section{EL SERVICIO NOTARIAL Y DE REGISTRO: DE LA JUDICIALIZACIÓN A LA COMPOSICIÓN DE CONFLICTOS COMO UN CONTRAPUNTO A LA BUROCRACIA ESTATAL}

\begin{abstract}
AfONSO SOARES OLIVEIRA SOBRINHO
Pós-Doutor em Direito pela Faculdade de Direito do Sul de Minas. Doutor em Direito pela Faculdade Autônoma de Direito de São Paulo - FADISP. Mestre em Políticas Sociais pela UNICSUL. Bacharel em Direito pela Universidade Federal de Alagoas. (São Paulo, SP, Brasil). http://lattes.cnpq.br/0200146123195594 / http://orcid.org/0000-0001-7098-5034 / afoadv.doc@gmail.com

Clarindo Ferreira Araujo Filho Doutorando em Direito pela Faculdade Autônoma de Direito de São Paulo - FADISP/SP. Mestre em Direito pelo Instituto Brasiliense de Direito Público - IDP/DF. Graduação em Direito pelo Centro Universitário de Brasília UNICEUB/DF. (São Paulo, SP, Brasil). http://lattes.cnpq.br/1632730313260999 / http://orcid.org/0000-0003-0282-1681 / clarindoaraujo@yahoo.com.br
\end{abstract}

\begin{abstract}
RESUMO
Os serviços notariais e de registro passaram por grandes transformações nas últimas décadas, no que foram eliminadas práticas antidemocráticas como os institutos da vitaliciedade e da hereditariedade, incompatíveis com os pressupostos do Estado Democrático de Direito. No entanto, a burocracia que hoje permeia praticamente todas as estruturas institucionais age como um entrave à realização de direitos. O principal objetivo deste estudo é fornecer subsídios para ampliar a consciência crítica no tocante a aspectos peculiares da evolução da atividade notarial e de registro no Brasil, e do seu atual alinhamento com as mudanças paradigmáticas da justiça brasileira, que hoje procura investir na composição de conflitos. A metodologia empregada neste estudo foi de cunho qualitativo e utilizou a pesquisa bibliográfica como principal meio para atingir os objetivos propostos. Conclui-se que o serviço notarial e de registro, no seu Múnus público, atua como um contraponto à burocracia estatal.
\end{abstract}

Palavras-chave: Burocracia; Justiça; Poder; Política.

\begin{abstract}
Registration and notary services underwent major transformations in the last decades in which anti-democratic practices such as the institutes of vitality and heredity, which are incompatible with the assumptions of the Democratic State of Law, were eliminated. However, the bureaucracy that currently exists in practically all institutional structures acts as a barrier to the realization of rights. The main objective of this study is to provide subsidies to increase critical awareness related to peculiar aspects of the evolution of notary and registry activities in Brazil, and of its current alignment with pragmatic changes of Brazilian Justice, which currently seeks to invest in the composition of conflicts. The methodology used in this study was qualitative and it used bibliographical research as the main means to reach the proposed objectives. It concludes that notary and registry services, in its public duty, act as a counterpoint to the state bureaucracy.
\end{abstract}

Keywords: Bureaucracy; Justice; Power; Policy. 


\section{RESUMEN}

Los servicios notarios y de registro pasaron por grandes cambios en las últimas décadas, en que se eliminaron prácticas antidemocráticas como los institutos de lo vitalicio y de la herencia, incompatibles con las premisas del Estado Democrático de Derecho. Sin embargo, la burocracia que hoy permea prácticamente todas las estructuras institucionales actúa como un obstáculo a la realización de derechos. El principal objetivo de este estudio es suministrar subsidios para ampliar la conciencia crítica con relación a los aspectos peculiares de la evolución de la actividad notarial y de registro en Brasil, y de su actual lineamiento con los cambios paradigmáticos de la justicia brasileña, que hoy procura investir en la composición de conflictos. La metodología empleada es de cuño cualitativo y se utilizó la investigación bibliográfica como principal medio para atingir los objetivos propuestos. Se concluye que el servicio notarial y de registro, en su función pública, actúa como un contrapunto a la burocracia estatal.

Palabras clave: Burocracia; Justicia; Poder; Política.

\section{SUMÁRIO}

INTRODUÇÃO; 1 POLÍTICA, PODER, TEORIA DOS JOGOS E ANTIFRAGILIDADE: OS CONTORNOS DE UM ESTADO DEMOCRÁTICO DE DIREITO QUE PROMOVE A DESIGUALDADE SOCIAL E ENCONTRA-SE EM EBULIÇÃO; 2 A TEORIA DOS JOGOS COMO MECANISMO AUXILIAR NA SOLUÇÃO DE CONTROVÉRSIAS; 3 SERVIÇO NOTARIAL E DE REGISTRO: A TRANSIÇÃO DA BUROCRACIA PÚBLICA COM VISTAS AO ACESSO À JUSTIÇA; CONCLUSÃO; REFERÊNCIAS.

\section{INTRODUÇÃO}

Hoje, no Brasil, há um rico debate acerca de novos esquemas para avaliação e melhor compreensão das estruturas do Estado Democrático de Direito. Essa é uma discussão que vem sendo erigida pelos brasileiros, como também por inúmeros outros povos no decorrer da história. Pouco a pouco, apesar da resiliência de tantos infortúnios, investigam-se fenômenos como as desigualdades econômicas e sociais, os interesses comumente dissimulados por parte de governantes, de representantes eleitos pelo povo e dos burocratas responsáveis pela organização e controle administrativo das instituições públicas e privadas.

Temas tormentosos como o sistema estatal de justiça e de pouca efetivação de direitos e, consequentemente, sobre os custos do sistema judiciário brasileiro, que impactam diretamente o erário público.

O problema é a utilização dos mesmos paradigmas econômico-financeiros das empresas privadas (eficiência, eficácia, efetividade, produtividade, custos etc.) na análise dos objetivos e performance do sistema judiciário, como se fosse uma panaceia capaz de extinguir as desigualdades sociais e as injustiças do sistema assim que se alcancem determinados índices propostos pelas ciências econômicas e administrativas.

Ora, a quem interessaria alta produtividade e taxas retorno, com baixíssimos custos, mas sem correlação direta com a realização de direitos, a participação democrática, a 
ISSN 1981-3694

(DOI): $10.5902 / 1981369425664$

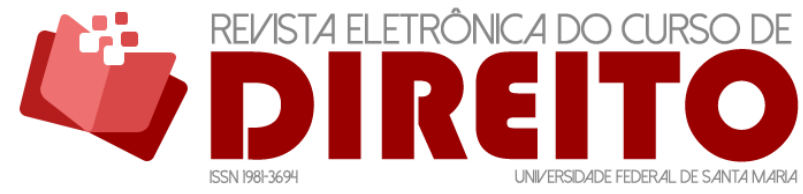

O SERVIÇO NOTARIAL E DE REGISTRO: DA JUDICIALIZAÇÃO À COMPOSIÇÃO DE CONFLITOS COMO UM CONTRAPONTO À BUROCRACIA ESTATAL

AFONSO SOARES OLIVEIRA SOBRINHO CLARINDO FERREIRA ARAUJO FILHO

transparência etc., senão aos que advogam as teses do Estado mínimo, da desregulamentação dos mercados e do laissez-faire, que somente concentram renda e ampliam o abismo da desigualdade social? A população e o erário público são impactados ora de maneira positiva, ora negativa pelas decisões tomadas, independentemente de esta burocracia localizar-se no judiciário, no legislativo ou no executivo.

Em que medida os serviços notariais e registrais, agora delegados efetivamente, conseguem realizar direitos constitucionalmente garantidos, como, por exemplo, o acesso à justiça, à publicitação e à segurança jurídica?

O principal objetivo deste estudo é fornecer subsídios para ampliar a consciência crítica no tocante a aspectos peculiares da evolução da atividade notarial e de registro no Brasil, e do seu atual alinhamento com as mudanças paradigmáticas da justiça brasileira, que hoje investe na composição de conflitos. A metodologia empregada foi de cunho qualitativo e utilizou-se a pesquisa bibliográfica como principal meio para atingir os objetivos propostos.

Várias das opiniões e conceitos emitidos ao longo deste texto foram selecionados nos bancos de dados da internet (banco de teses da USP, periódicos da Capes, do Ipea etc.) e nas bibliotecas da USP e da UNB. Estes refletem, em boa medida, as opiniões de renomados autores nacionais e internacionais, especialistas em direito, doutrinadores, acadêmicos estudiosos de economia, sociologia, antropologia, filosofia e história. Isso acabou por tornar a pesquisa bibliográfica o principal meio de pesquisa deste estudo que, juntamente com a experiência profissional e acadêmica dos autores, serviu para amalgamar tanto o trabalho interpretativo prévio como o posterior, a respeito de temas como as relações de poder social, econômico e legal, que são influenciadas direta e indiretamente pela burocracia, bem como pela "antifragilidade" dessa burocracia que se fortalece mais e mais no seio do Estado Democrático de Direito.

A principal justificativa para a realização desta pesquisa é que existe uma tendência mundial em se promover uma espécie de metamorfose às avessas, em que os outrora problemas políticos se transformam em problemas burocráticos. Para os políticos profissionais, tem sido recorrente nomear um "bode expiatório" - no caso específico, a burocracia - do que enfrentar o problema da cultura da litigiosidade e promover mudanças que melhorem a representatividade, a participação, a transparência e a democratização das estruturas burocráticas, quer sejam governamentais, quer pertençam a outras esferas institucionais (iniciativa privada, terceiro setor, organizações populares etc.). 
O artigo encontra-se organizado em tópicos. Inicialmente, a introdução traça um breve cenário dos temas a serem abordados, as principais questões que serão aprofundadas, assim como a delimitação dos objetivos, da metodologia e a justificativa para a elaboração do trabalho. No primeiro tópico, abordam-se diversos paradigmas relacionados à política, ao poder, e ao conceito de "antifragilidade", como originalmente colocado por Nassim Nicholas Taleb", e de como tais paradigmas interagem para justificar a razão de ser de instituições, tais como o Estado, os poderes da República e outras que legitimam formas de exploração econômica e social dos membros da sociedade civil. O segundo tópico discute a Teoria dos Jogos aplicada às soluções extrajudiciais de conflitos, seja pela mediação ou negociação envolvendo a administração pública. 0 terceiro tópico serve para situar o leitor na grande teia formada pela burocracia, tanto estatal como não estatal, e que vem adquirindo uma complexidade preocupante, pois em boa parte das ocasiões acaba por dificultar mais ainda a realização de direitos de pessoas e de instituições. Conclui-se que a burocracia estatal se revela nas desigualdades e na falta de oportunidades a todos, inclusive de acesso à justiça. 0 notariado brasileiro pode servir como instrumento ao cidadão que necessita do acesso à justiça - com rapidez e eficiência - pela via extrajudicial.

\section{POLÍTICA, PODER E ANTIFRAGILIDADE: OS CONTORNOS DE UM ESTADO DEMOCRÁTICO DE DIREITO QUE PROMOVE A DESIGUALDADE SOCIAL E ENCONTRA-SE EM EBULIÇÃO}

Sobre política, em plena Grécia Antiga, Aristóteles já relatava como as desigualdades contribuíam para as revoltas e dificuldades que os membros da classe dominante, representada principalmente pelos políticos, tinham em não se corromper pelas tentações advindas do exercício do poder público ${ }^{2}$. 0 estagirita destacava a necessidade de observância às liberdades e

\footnotetext{
${ }^{1}$ TALEB, Nassim Nicholas. Antifrágil. Rio de Janeiro: Best Business, 2014.

2 "Uma ironia perpassa o texto aristotélico, bom como as lembranças de velhos tempos nos quais os cargos eram exercidos em prol da vida citadina. Já em sua época, pois, importa assinalar, advertia: as vantagens adquiridas a partir da fortuna pública acabariam por corromper os magistrados, em sua luta mesquinha por cargos e por sua perpetuação nos mesmos. Aristóteles, portanto, conquanto a tomasse como instrumento positivo, entrevira, mesmo que em traços abstratos, a inevitável corrupção inerente à política, efetividade que a constitui intestinamente. $O$ que não poderia antever, porque historicamente impossível, é que a corrupção avistada não é de talhe individual, pessoal e ético; mas, ao revés, atributo intestino e inseparável, endêmico, como a história demonstraria. Mesmo assim, o estagirita percebera que algo não ia bem e que, nesse sentido, demandava esforços ainda maiores da ética, não obstante sua enorme impotência" CHASIN, Milene. Política, limite e mediania em Aristóteles. 2007. Tese (Doutorado
} 
às leis como prática salutar das repúblicas sabiamente moderadas e, ao mesmo tempo, a dificuldade em sua conservação e o risco de dissolução em caso de deturpação da lei ${ }^{3}$.

[...] A ilegalidade surge às vezes sem ser percebida, como as pequenas despesas que, sempre repetidas, dilapidam as fortunas. A despesa parece insensível porque não é feita de uma vez. O espírito se ilude; é o caso do conhecido sofisma: sendo cada parte pequena, também o todo é pequeno. Isso às vezes é verdade, mas não sempre, porque o todo ou conjunto nem sempre é pequeno, embora se componha de partes pequenas. É preciso, pois, antes de tudo, por-se em guarda contra tais princípios e desconfiar dos sofismas habilmente engendrados para enganar a multidão, porque os próprios fatos os refutam. ${ }^{4}$

Alexis de Tocqueville, ainda no século XIX, também descreveu alguns dos sentimentos de medo, preconceito e o ceticismo que rondam a humanidade há séculos: o medo de ver em qualquer nova teoria um perigo indissociável, o preconceito de acreditar que toda inovação não passaria apenas de mais um problema penoso que necessita ser enfrentado, a visão cética de que todo o progresso social seria afinal mais um passo no rumo das revoluções e dos conflitos armados, e que, portanto, a melhor coisa a fazer é não se mexer ${ }^{5}$.

Entre os medos de Aristóteles e a paralisia descrita por Tocqueville, hoje os dilemas políticos aparentam concentrar-se nos percalços da democracia representativa e suas complexas relações, em que o compartilhamento do poder ora é açambarcado por um dos poderes, ora por outro, o que termina por incentivar disputas quase sempre prejudiciais à almejada e necessária harmonia e estabilidade institucional ${ }^{6}$.

Por sua vez, os desafios impostos pelas demandas crescentes da sociedade atual emprego e renda, segurança, liberdade, acesso, saúde, educação, dignidade etc.- podem até

em História Social) - Faculdade de Filosofia, Letras e Ciências Humanas, Universidade de São Paulo, São Paulo, 2007. Disponível em: <http://www.teses.usp.br/teses/disponiveis/8/8138/tde-04122007110142/pt-br.php>. Acesso em: 15 set. 2016. p. 244.

3 ARISTÓTELES. A política. Tradução de Nestor Silveira Chaves. Bauru: Edipro, 1995. Série Clássicos. p. $281-282$.

${ }^{4}$ ARISTÓTELES. A política. Tradução de Nestor Silveira Chaves. Bauru: Edipro, 1995. Série Clássicos. p. 282.

${ }^{5}$ TOCQUEVILLE, Alexis de. A democracia na América: leis e costumes de certas leis e certos costumes políticos que foram naturalmente sugeridos aos americanos por seu estado social democrático. 2. ed. São Paulo: Martins Fontes, 2005.

"Na visão de Luciana da Silva Costa, existe um "estreitamento" nas relações políticas e de poder constitucionalmente conduzidas, em que há uma concentração de poder na mão de poucos. COSTA, Luciana da Silva. A revisitação do princípio da separação de poderes: dialogicidade e tensão como elementos conformadores da identidade constitucional brasileira. 2014. Tese (Doutorado em Direito do Estado) - Faculdade de Direito, Universidade de São Paulo, São Paulo, 2014. Disponível em: <http://www.teses.usp.br/teses/disponiveis/2/2134/tde-21012015-091338/pt-br.php>. Acesso em: 15 set. 2015. 
mesmo provocar uma sensação de paralisia, um torpor diante das complexas situações e escolhas difíceis diante das quais somos obrigados a nos posicionar diariamente, quer seja na administração da vida privada, quer nas escolhas de nossos representantes pelo voto ${ }^{7}$.

No plano do indivíduo, o pensamento weberiano descreve dois tipos ideais ${ }^{8}$, modelos abstratos que servem para apoiar o raciocínio - o "especialista sem espírito" e o "homem do prazer sem coração" - que, juntos, competem por um lugar ao sol na sociedade globalizada e excludente conforme descreve Sousa ${ }^{9}$. Ora, 0 desenvolvimento ${ }^{10}$ sem precedentes experimentado ao longo do último século nos conduziu a um novo conjunto de problemas. Estes apresentam como principal característica soluções de difícil implementação, que não devem envolver violência e guerra, exploração do homem pelo homem, mortes, miséria, perpetuação das desigualdades sociais etc.

Segundo Jessé Sousa, atualmente, no Brasil, existe um embate acadêmico envolvendo ideologias políticas entre os denominados "liberais-conservadores"11 de um lado, e um outro grupo, formado pelos que se cognominam "politicamente corretos"12.

\footnotetext{
${ }^{7}$ Esta também é a linha de raciocínio de Tony Judt ao discorrer sobre as transformações do continente europeu no pós-guerra, prática hoje transcontinental por conta da internacionalização da economia e da cultura globalizada. Para melhor compreensão deste fenômeno, ler JUDT, Tony. Um tratado sobre os nossos atuais descontentamentos. Lisboa: Edições 70, 2012.

8 “'[...] o 'especialista sem espírito', que tudo conhece sobre seu pequeno mundo de atividade e nada sabe (nem quer saber) acerca de contextos mais amplos que determinam seu pequeno mundo, e, por outro, o 'homem do prazer sem coração', que tende a amesquinhar seu mundo sentimental e emotivo à busca de prazeres momentâneos e imediatos. Se a primeira leitura fornece o estofo para a apologia liberal do mercado e do sujeito percebido como independente da sociedade e de valores supraindividuais, a segunda marcou profundamente toda a reflexão crítica da sociedade moderna até nossos dias. A percepção do indivíduo moderno como suporte das ilusões da independência absoluta e da própria perfeição narcísica (quando, na verdade, realiza sem saber todas as virtualidades de uma razão instrumental que termina em consumismo e conformismo político) está na base de grande parte das vertentes críticas mais influentes do século XX" SOUSA, Jessé. A tolice da inteligência brasileira: ou como o país se deixa manipular pela elite. São Paulo: LeYa, 2015. p. 3-4.

9 SOUSA, Jessé. A tolice da inteligência brasileira: ou como o país se deixa manipular pela elite. São Paulo: LeYa, 2015. p. 3-4.

${ }^{10} \mathrm{O}$ imperativo do desenvolvimento suscitou a consciência crítica. Não é esta uma explicação suscetível de ser generalizada para todos os grupos sociais em que o fenômeno tem ocorrido. Cada caso tem seu diagnóstico particular. Este terreno, aliás, ultrapassa o domínio da sociologia, tal como aqui se tem entendido a disciplina, e somente com o concurso da filosofia e, mais particularmente, da filosofia da cultura, pode ser explorado. A autoconsciência coletiva e a consciência crítica são produtos históricos. Surgem quando um grupo social põe entre si e as coisas que o circundam um projeto de existência. RAMOS, Alberto Guerreiro. A redução sociológica. 3. ed. Rio de Janeiro: UFRJ, 1996. p. 46.

${ }^{11}$ Para Jessé Sousa, a pobreza do debate político brasileiro se expressa pela má colocação de termos como liberal e conservador, muito usados pelos estadunidenses e pouco compreendidos em terras brasileiras: “[...] Nos Estados Unidos, 'liberal' tem uma conotação oposta da que tem no Brasil. Nos Estados Unidos, 'liberal' é aquele indivíduo que quase sempre vota no partido democrata, quer mais impostos para dividir uma enorme riqueza pessimamente distribuída e acha que o Estado deve ajudar na saúde e na educação. Liberal aqui tem aquele sentido de união do interesse particular, garantia de liberdades individuais,
} 
Este embate, na verdade, serve apenas para dissimular sistemas de ideias e os gravíssimos problemas de criação de oportunidades e de realização de direitos, principalmente das populações menos abastadas ${ }^{13}$. Riqueza e privilégios são recursos escassos em qualquer Estado Democrático de Direito contemporâneo, o problema é como certos grupos, na maioria das vezes politicamente bem representados, procuram justificar seus métodos de acesso a tais recursos escassos. Normalmente, fazendo uso de discursos ideologicamente ${ }^{14}$ elaborados, endereçados àqueles com pequena compreensão política e social, os manipuláveis. No entanto, tais discursos são mal fundamentados para outros, que percebem as segundas intenções de

comum noção de justiça pública, do interesse comum, portanto, que caracteriza essa noção mais generosa de liberalismo tão ao gosto de Tocqueville. O liberal brasileiro, mesquinho e autoindulgente [...] seria o 'conservador' americano, o indivíduo que vota no partido republicano, vota contra qualquer imposto e quer um Estado mínimo e, se possível, inexistente [...] 0 problema, típico de um país com um debate político pobre e pouco crítico, é que entre nós é possível 'ser' conservador e 'se passar' por crítico e progressista. Se o 'conservador' americano não tem medo de se chamar pelo nome, o liberal-conservador brasileiro gosta de ser visto como 'progressista' e 'dizer' aquilo que é o contrário do que 'faz'” E ainda, “[...] o 'liberal-conservador' culpa a vítima pelo próprio fracasso para usufruir de seus privilégios sem má consciência, o 'politicamente correto' trata de 'idealizar' e de 'romantizar' o oprimido, como se fossem representações conscientes a causa da dominação social e apenas bastasse a 'boa vontade cristã' para reverter o quadro de dominação injusta. Assim, mantém-se a leitura superficial da realidade do nosso liberalismo conservador, que não percebe a 'estrutura profunda' que faz a dominação social se reproduzir de modo aparentemente 'legítimo', e 'idealizar-se' a vítima, apenas por ser vítima”. SOUSA, Jessé. Ralé brasileira: quem é e como vive. Belo Horizonte: UFMG, 2009. p. 90.

12 SOUSA, Jessé. Ralé brasileira: quem é e como vive. Belo Horizonte: UFMG, 2009. p. 9.

${ }^{13}$ FAORO, Raymundo. Os donos do poder: formação do patronato político brasileiro. 3. ed. São Paulo: Globo, 2001;

SOUSA, Jessé. Ralé brasileira: quem é e como vive. Belo Horizonte: UFMG, 2009;

TRAGTENBERG, Maurício. A falência da política. São Paulo: Unesp, 2009. Disponível em: $<$ https: / / books.google.com.br/books?id=BmsDafV7y60C\&printsec=frontcover\&hl=ptPT\#v=onepage\&q\&f=fal se>. Acesso em: 19 set. 2016.

${ }^{14}$ Nesse sentido, ressalte-se a discussão sobre ideologia traçada por Alba Zaluar: “[...] 0 efeito de ilusão da ideologia não é comentado para que seu caráter sistemático, ordenado e racional de ideias abstratas ou a percepção clara do papel histórico e do lugar que a classe ocupa na totalidade social domine todo o palco da reflexão teórica. Quando levado às últimas consequências, esta concepção de ideologia implica uma consciência radical ou crítica que realiza uma reflexão total da sociedade da qual só a atividade teórica dos intelectuais é capaz [...] tendo-se esse modelo teórico como referencial, as crenças, os valores e as atitudes desenvolvidos ou mesmo criados no cotidiano das pessoas comuns estariam por assim dizer num vazio ideológico ou no terreno das ilusões e crenças irracionais. As massas desagregadas, de baixo nível educacional, estariam, portanto, fora do processo de produção de ideias, sendo apenas portadores (ou 'suportes') do que foi produzido de fora para elas ou meros receptores passivos dos mecanismos de dominação e das estratégias políticas dos que detêm o poder, elas mesmas incapazes de pensar criticamente sobre o poder que as oprime. Meros executores de um projeto que não criaram e fantoches de uma direção que não veem mas que os comanda de todo lugar, perdem por decreto teórico sua condição de sujeitos ativos [...] Sua prática reduz-se ao plano do imediato: o imediatamente sensível, o imediatamente perdido, sendo a execução mecânica de algo que thes escapa. Sua linguagem, sua fala, seus rituais e suas crenças são sempre defeitos de percepção, empecilhos à consciência crítica: prisioneiros dos aparelhos ideológicos ou dos dispositivos do poder, seriam seres humanos mutilados, cegos diante da opacidade da estrutura. Esta só é desvelada na atividade do observador absoluto [...]" ZALUAR, Alba. A máquina e a revolta: as organizações populares e o significado da pobreza. 2. ed. São Paulo: Brasiliense, 1994. p. 52. 
grupos que tão somente desejam a qualquer custo manter o status quo. Enquanto uns, por exemplo, promovem o ideal da justiça social e da ampliação de oportunidades para todos os cidadãos, apoiados pelas ideias de um constitucionalismo dinâmico e justo, outros ${ }^{15}$, por sua vez, advogam pela concentração de renda e pela manutenção de políticas que só perpetuam as desigualdades ${ }^{16}$. Infere-se daí que por conta do atual estágio de desenvolvimento econômico e social alcançado por nosso país, os grandes problemas a serem enfrentados localizam-se principalmente na esfera da política, segundo a visão de Florestan Fernandes:

Como sucedeu com várias sociedades nacionais, que participam do mesmo círculo civilizatório, o Brasil já atingiu um nível de diferenciação social que converte os seus problemas de mudança em problemas fundamentalmente políticos. Eles são problemas políticos em três sentidos distintos: a) por dependerem ou resultarem de mecanismos de ação grupal que traduzem as posições relativas dos grupos na estrutura de poder da sociedade nacional; b) por exprimirem a natureza e o grau de poder alcançado por determinados grupos tanto na universalização de seus interesses, ideologias e valores sociais quanto no controle dos processos que afetam socialmente, de modo direto ou indireto, a manifestação daqueles interesses, ideologias e valores sociais; c) por indicarem em que sentido e dentro de que limites a organização da sociedade absorve, protege e expande, institucionalmente, as condições que são essenciais para o seu equilíbrio interno. ${ }^{17}$

Como bem assevera Jessé Sousa, "Igualdade e desigualdade se decidem por chances concretas de acesso a bens materiais e simbólicos escassos e que pressupõem luta e competição social" ${ }^{18}$. E a política e, por conseguinte, o jogo de poder a ela associado ${ }^{19}$, é quem promove o

${ }^{15}$ Uma das premissas do pensamento weberiano é bem exposta por Jessé Sousa quando discorre sobre legitimação: "[...] os ricos e privilegiados não querem apenas ser mais felizes, eles querem também se sentir 'legitimados' no privilégio. Para isso é sempre necessário travestir a defesa dos próprios interesses particulares com se estes representassem a virtude universal. A quem interessa, afinal, culpar a má administração do Estado pelas mazelas sociais, cortar gastos públicos, pedir Estado mínimo, culpar os pobres pelo fracasso, obscurecer conflitos, deixar que a busca de lucro seja o único princípio em todas as esferas sociais e interpretar o próprio sucesso como fruto 'meritocrático' do próprio talento visto como 'natural'?". SOUSA, Jessé. Ralé brasileira: quem é e como vive. Belo Horizonte: UFMG, 2009. p. 87.

${ }^{16}$ FAORO, Raymundo. Os donos do poder: formação do patronato político brasileiro. 3. ed. São Paulo: Globo, 2001;

SOUSA, Jessé. Ralé brasileira: quem é e como vive. Belo Horizonte: UFMG, 2009;

TRAGTENBERG, Maurício. A falência da política. São Paulo: Unesp, 2009. Disponível em: <https://books.google.com.br/books?id=BmsDafV7y60C\&printsec=frontcover\&hl=ptPT\#v=onepage\&qAf=fal se>. Acesso em: 19 set. 2016.

${ }^{17}$ FERNANDES, Florestan. Sociedade de classes e subdesenvolvimento. 5. ed. São Paulo: Global, 2008. p. 104-105.

${ }^{18}$ SOUSA, Jessé. Ralé brasileira: quem é e como vive. Belo Horizonte: UFMG, 2009. p. 75-76.

19 "A política, por sua vez, parece reunir seus variados matizes de significado na "boca do povo" em torno de um deles cada vez mais claro: a luta pelo poder, o conflito que procura a destruição do adversário. $\mathrm{E}$ os políticos, por causa disso, vêm sendo investidos de uma representação cada vez mais negativa, com 
tom e gradua a medida em que tais acessos, teoricamente, devam encontrar-se positivados no texto das Constituições contemporâneas. ${ }^{20}$

De acordo com Raymundo Faoro, defensor da tese do "patrimonialismo/personalismo"21 e, também, de Marilena Chauí, que traça um esboço sobre “mito fundador”22, as lições extraídas da história deveriam servir para explicar boa parte das persistentes mazelas atribuídas ao Estado brasileiro e à sua burocracia inepta, patrimonialista, corrupta, corporativista, excludente, clientelista etc.

Instituições são grupos sociais organizados tanto de maneira formal como informalmente. Neste estudo, a expressão instituição ${ }^{23}$ assume diversas acepções. Instituição pode ser, por exemplo, uma família, um jogo desportivo, uma torcida organizada ou mesmo um

algumas poucas exceções" ZALUAR, Alba. A máquina e a revolta: as organizações populares e o significado da pobreza. 2. ed. São Paulo: Brasiliense, 1994. p. 219.

${ }_{20}$ "Uma Constituição é de fato uma Lei Fundamental, e como tal deve ser vista pelo juiz. Cabe a ele, portanto, definir tanto o seu significado quanto o de qualquer ato particular procedente do corpo legislativo, detalhando as cláusulas constitucionais gerais e abstratas, uma vez que a Constituição não é um mero conjunto de normas impositivas, que vinculam, de forma indiscutível, as gerações futuras (the agency problem): ao contrário, deve se reconhecer a possibilidade de esta ser compreendida à luz da realidade vigente, de modo a permitir o engajamento da geração presente na defesa dos direitos concebidos em outros momentos". VALLE, Vanice Regina Lírio do (Org.). Ativismo jurisdicional e o Supremo Tribunal Federal: Laboratório de Análise Jurisprudencial do STF. Curitiba: Juruá, 2009. p. 72.

21 "A longa caminhada dos séculos na história de Portugal e do Brasil mostra que a independência sobranceira do Estado sobre a nação não é a exceção de certos períodos, nem o estágio, o degrau para alcançar outro degrau, previamente visualizado [...] 0 estamento burocrático, fundado no sistema patrimonial do capitalismo politicamente orientado, adquiriu o conteúdo aristocrático, da nobreza de toga e do título. A pressão da ideologia liberal e democrática não quebrou nem diluiu, nem desfez o patronato político sobre a nação, impenetrável ao poder majoritário, mesmo na transação aristocrático-plebéia do elitismo moderno [...]" FAORO, Raymundo. Os donos do poder: formação do patronato político brasileiro. 3. ed. São Paulo: Globo, 2001. p. 885.

${ }^{22}$ Sobre o conceito de "mito fundador", Marilena Chauí defende que: "Ao falarmos em mito, nós o tomamos não apenas no sentido etimológico de narração pública de feitos lendários da comunidade, isto é, no sentido grego da palavra mythos, mas também no sentido antropológico, na qual essa narrativa é a solução imaginária para tensões, conflitos e contradições que não encontram caminhos para serem resolvidos no nível da realidade. Se também dizemos mito fundador é porque, à maneira de toda fundatio, esse mito impõe um vínculo interno com o passado como origem, isto é, com um passado que não cessa nunca, que se conserva perenemente presente e, por isso mesmo, não permite o trabalho da diferença temporal e da compreensão do presente enquanto tal. Nesse sentido, falamos em mito também na acepção psicanalítica, ou seja, como impulso à repetição de algo imaginário, que cria um bloqueio à percepção da realidade e impede lidar com ela" CHAUÍ, Marilena. Brasil: mito fundador e sociedade autoritária. São Paulo: Perseu Abramo, 2000. p. 9.

${ }_{23}$ "No mínimo uma instituição não passa de uma convenção [...] uma convenção surge quando todos os lados têm interesse comum na existência de uma regra que assegure a coordenação, quando nenhum deles apresenta interesses conflitantes e quando nenhum deles se desviará, a menos que a desejada coordenação se tenha perdido [...] Assim, nessa medida, por definição, uma convenção se autopolicia. 0 fato de a aldeia ' $A$ ' realizar seu mercado na sexta-feira ou no sábado é indiferente, contanto que ele não aconteça no mesmo dia que o da aldeia vizinha 'B'. Ninguém se importa qual lado da estrada é a regra para os que guiam, mas todos querem que exista uma regra" DOUGLAS, Mary. Como as instituições pensam. São Paulo: Universidade de São Paulo, 1998. p. 58. 
poder da república, o congresso nacional, uma grande corporação privada etc. Esta ideia também se relaciona com a de autoridade legitimadora, cujos intercâmbios servem para nos ajudar na compreensão de inúmeros fenômenos relacionados com a burocracia e suas distorções ${ }^{24}$.

Outro importante conceito correlato aos fenômenos da burocracia e dos jogos de poder institucionais é o da racionalidade dos agentes (racionalidade formal instrumental e racionalidade valorativa substancial) ${ }^{25}$, como descritas originalmente por Max Weber ${ }^{26}$, que tem como ponto de partida fenomenológico a ideia de "gestão econômica". Assim:

Chamamos racionalidade formal de uma gestão econômica o grau de cálculo tecnicamente possível e que ela realmente aplica. Ao contrário, chamamos racionalidade material o grau em que o abastecimento de bens de determinados grupos de pessoas ocorra conforme determinados postulados valorativos (qualquer que seja sua natureza) que constituem o ponto de referência pelo qual este abastecimento é, foi ou poderia ser julgado. Estes postulados têm significados extremamente variados. ${ }^{27}$ (grifo do autor)

Esses tipos de racionalidade influenciam a forma como os agentes públicos e privados tomam suas decisões no ambiente institucional, no qual a burocracia impera alicerçada pelas leis e normas ${ }^{28}$. Por último, há de se considerar a “antifragilidade" ${ }^{29}$, termo cunhado por Taleb

${ }^{24}$ DOUGLAS, Mary. Como as instituições pensam. São Paulo: Universidade de São Paulo, 1998; MOTTA, Fernando C. Prestes. Organização e poder: empresa, Estado e escola. São Paulo: Atlas, 1986; SOUSA, Jessé. Ralé brasileira: quem é e como vive. Belo Horizonte: UFMG, 2009.

${ }^{25} \mathrm{Na}$ visão weberiana, existem dois tipos fundamentais de racionalidade: "Zwerckrationalitat, ou racionalidade formal instrumental, um processo que acima de tudo visa resultados, fins específicos. Em última análise, esta racionalidade se resume em um cálculo de adequação meios-fins, onde os fins são dados a priori e a dinâmica do raciocínio se dirige à instrumentalização dos recursos para atingir esses fins. Wertrationalitat ou, então, racionalidade valorativa substancial, um processo diverso da adequação meio-fim e voltado, primordialmente, à elaboração de referências que servem de base para expectativas de valores, ao menos em tese, independentes das expectativas de sucesso imediato, gerando ações que se orientam para as propriedades intrínsecas dos atos. Esses dois tipos de racionalidade não existem socialmente, em uma separação ideal, mas se mesclam continuamente na vida diária. Mas o inegável crescimento da aplicação da racionalidade formal-instrumental é peculiar aos sistemas inseridos na economia de mercado, em geral, e aos sistemas burocráticos, em particular [...]" VASCONCELOS, Flávio Carvalho de. Racionalidade, autoridade e burocracia: as bases da definição de um tipo organizacional pósburocrático. Revista de Administração Pública, Rio de Janeiro, v. 38, n. 2, p. 201-202, mar./abr. 2004.

${ }^{26}$ WEBER, Max. Economia e sociedade: fundamentos da sociologia compreensiva. Brasília: Universidade de Brasília; São Paulo: Imprensa Oficial do Estado de São Paulo, 1999.

${ }^{27}$ WEBER, Max. Economia e sociedade: fundamentos da sociologia compreensiva. Brasília: Universidade de Brasília; São Paulo: Imprensa Oficial do Estado de São Paulo, 1999. p. 52.

${ }^{28}$ VASCONCELOS, Flávio Carvalho de. Racionalidade, autoridade e burocracia: as bases da definição de um tipo organizacional pós-burocrático. Revista de Administração Pública, Rio de Janeiro, v. 38, n. 2, p. 201-202, mar./abr. 2004.

SOUZA, Jessé. A tolice da inteligência brasileira: ou como o país se deixa manipular pela elite. São Paulo: LeYa, 2015. 
ISSN 1981-3694

(DOI): $10.5902 / 1981369425664$

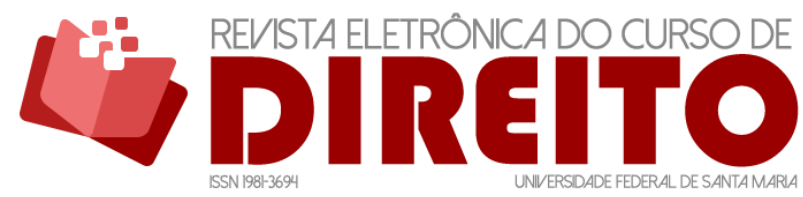

O SERVIÇO NOTARIAL E DE REGISTRO: DA JUDICIALIZAÇÃO À COMPOSIÇÃO DE CONFLITOS COMO UM CONTRAPONTO Ã BUROCRACIA ESTATAL

AFONSO SOARES OLIVEIRA SOBRINHO CLARINDO FERREIRA ARAUJO FILHO

para designar coisas que se favorecem de impactos, e que se fortalecem à medida que são expostas à volatilidade, à desordem e a toda espécie de agentes causadores de estresse, e que com isso acabam demonstrando afinidades com o risco e a incerteza e se fortalecendo paulatinamente.

Entenda-se que "antifragilidade" não é apenas uma espécie de resiliência ou mesmo de robustez, porque enquanto que a resiliência é uma qualidade que demonstra a capacidade das coisas em resistir a impactos, o “antifrágil”, além de resistir, torna-se ainda mais forte e melhor toda vez que enfrenta e sai vencedor a variados tipos de agentes estressores, e isso de certa forma nos ajuda a compreender melhor tudo aquilo que demonstra ser frágil e sensível à volatilidade e aos impactos estressantes ${ }^{30}$.

Descritos sucintamente os principais pressupostos e conceitos - política, instituições, ideologia, burocracia, "antifragilidade" -, é chegado o momento de fazer uma incursão nos conhecimentos oriundos da matemática, da economia e das ciências sociais para clarificar as ideias em torno da Teoria dos Jogos $^{31}$ e como ela pode ser utilizada para explicar a solidificação das instituições burocráticas no mundo hodierno. Além disso, como o sistema notarial e registral vem adquirindo pouco a pouco uma notável "antifragilidade".

WEBER, Max. Economia e sociedade: fundamentos da sociologia compreensiva. Brasília: Universidade de Brasília; São Paulo: Imprensa Oficial do Estado de São Paulo, 1999.

${ }^{29}$ Para Taleb, a antifragilidade é uma propriedade de tudo aquilo que vem resistindo e se fortalecendo com o passar dos séculos, abrangendo um variado leque que inclui de manifestações sociais a formas de vida, além de diversos tipos de fenômenos, desde econômicos até biológicos, como a resistência desenvolvida por bactérias contra antibióticos etc. TALEB, Nassim Nicholas. Antifrágil. Rio de Janeiro: Best Business, 2014.

${ }^{30}$ TALEB, Nassim Nicholas. Antifrágil. Rio de Janeiro: Best Business, 2014.

31 "A origem da teoria dos jogos está diretamente relacionada ao nome do matemático John von Neuman (1903-1957) [...] sua primeira publicação sobre jogos data de 1928 [...] na qual demonstra que a solução para jogos de soma zero (jogos em que o ganho de um jogador representa necessariamente uma perda para o outro) pode ser determinada utilizando-se técnicas matemáticas. A análise dos jogos de soma zero viria a ser desenvolvida mais tarde em seu livro The Theory of Games and Economic Behavior, publicado em 1944 e escrito em coautoria com o economista alemão Oskar Morgenstern (1902-1977), também emigrado para os Estados Unidos. Além de jogos de soma zero, The Theory of Games and Economic Behavior também definiu a representação de jogos em forma extensiva, em que são identificadas as decisões de cada jogador em cada estágio do jogo, quando o jogo se desenvolve em etapas sucessivas; e discutiu cooperação e formação de coalizões entre jogadores [...]" FIANI, Ronaldo. Teoria dos Jogos com aplicações em economia, administração e ciências sociais. 3. ed. Rio de Janeiro: Elsevier, 2009. p. 3536. 


\section{A TEORIA DOS JOGOS COMO MECANISMO AUXILIAR NA SOLUÇÃO DE CONTROVÉRSIAS}

A Teoria dos Jogos, como descrita na obra de John von Neuman, The Theory of Games and Economic Behavior, ainda apresentava limitação pelo fato de descrever apenas certos tipos de jogos de soma zero, normalmente com um número reduzido de competidores e tipos de interações possíveis entre eles. Isso limitava sua aplicação diante de fenômenos sociais que surgiam com uma grande quantidade de interações entre os agentes ${ }^{32}$.

Assim, os jogos de soma zero e o exercício teórico proporcionado pelas análises dos intercâmbios entre uma quantidade razoável de agentes econômicos e suas organizações, particularmente no campo das ciências econômicas, apresentavam restrições que acabavam por dificultar sua aplicabilidade em modelos que representassem situações concretas do dia a dia. Foi quando John F. Nash Jr. ${ }^{33}$, John C. Harsanyi e Reinhard Selten desenvolveram ferramentas matemáticas capazes de contornar tais restrições e que acabaram por premiá- $\operatorname{los}^{34}$ com o Nobel

32 DAMIANI, Gerson Denis Silvestre Duarte. Teoria dos jogos e relações internacionais: estratégias da governança mercantil global. Uma análise da convenção das Nações Unidas para os contratos de compra e venda internacional de mercadorias à luz de sua vinculação ao Brasil. 2014. Tese (Doutorado em Relações Internacionais) - Instituto de Relações Internacionais, Universidade de São Paulo, São Paulo, 2014. Disponível em: <http://www.teses.usp.br/teses/disponiveis/101/101131/tde-08102014-171811/ptbr.php>. Acesso em: 15 set. 2016;

FIANI, Ronaldo. Teoria dos Jogos com aplicações em economia, administração e ciências sociais. 3. ed. Rio de Janeiro: Elsevier, 2009.

33 "Na evolução da Teoria dos Jogos, um conceito merecedor de espaço singular é o Equilíbrio Nash, também conhecido como Equilíbrio Não-Cooperativo, e possivelmente o tema mais difundido entre os estudiosos e mesmos os leigos da Teoria dos Jogos, devido ao seu amplo reconhecimento e escopo de aplicação. Trata-se de um conceito de solução de jogo envolvendo um ou mais atores, onde cada ator escolhe a melhor estratégia para si próprio, partindo-se do pressuposto que cada ator conhece as estratégias de equilíbrio dos outros atores, e nenhum ator se beneficia ao alterar sua própria estratégia de jogo unilateralmente. Se cada ator escolheu uma estratégia e nenhum ator pode beneficiar-se pela mudança de sua própria estratégia, na medida em que as estratégias dos outros atores permanecem inalteradas, então as escolhas de estratégia e seus respectivos benefícios constituem o Equilíbrio Nash [...]" DAMIANI, Gerson Denis Silvestre Duarte. Teoria dos jogos e relações internacionais: estratégias da governança mercantil global. Uma análise da convenção das Nações Unidas para os contratos de compra e venda internacional de mercadorias à luz de sua vinculação ao Brasil. 2014. Tese (Doutorado em Relações Internacionais) - Instituto de Relações Internacionais, Universidade de São Paulo, São Paulo, 2014. Disponível em: <http://www.teses.usp.br/teses/disponiveis/101/101131/tde-08102014-171811/ptbr.php>. Acesso em: 15 set. 2016. p. 25.

${ }^{34}$ DAMIANI, Gerson Denis Silvestre Duarte. Teoria dos jogos e relações internacionais: estratégias da governança mercantil global. Uma análise da convenção das Nações Unidas para os contratos de compra e venda internacional de mercadorias à luz de sua vinculação ao Brasil. 2014. Tese (Doutorado em Relações Internacionais)-Instituto de Relações Internacionais, Universidade de São Paulo, São Paulo, 2014. Disponível em: <doi: 10.11606/T.101.2014.tde-08102014-171811>. Acesso em: 15 set. 2016; FIANI, 
de Economia em 1994. Assim, por meio das ferramentas matemáticas desenvolvidas por John F. Nash Jr., foi possível ampliar a visão da Teoria dos Jogos para além daquelas situações dos jogos de soma zero 35 .

Ora, Mary Douglas lembra a necessidade de se levar em conta o tamanho e a complexidade dos grupos sociais e seu conjunto de interações, que nem é pautado por escolhas em que impera a racionalidade, quando se tenta, por exemplo, realizar análises que consideram teorias como as dos jogos, cujos pressupostos consideram as ações e reações de agentes que fazem escolhas racionais ${ }^{36}$.

Seria o caso das escolhas realizadas pelos agentes políticos, ao exercerem suas prerrogativas legiferantes, ao consumar, por exemplo, a mudança das instituições e da sua burocracia sem resolver problemas de desigualdades que impedem que todos tenham acesso às mesmas oportunidades. Isso fica evidente nas relações de poder e de domínio das técnicas de acesso aos serviços ofertados pelo Estado e nas condições materiais que permitem concorrer em igualdade de condições. Haja vista a desigualdade social existente em nosso país, que cria um verdadeiro abismo entre os candidatos oriundos das classes mais abastadas e aqueles que nasceram na pobreza ${ }^{37}$. Portanto, as crianças das classes média e alta, desde a primeira infância recebem dos pais diversos tipos de estímulos, bons exemplos de vida acadêmica e profissional,

Ronaldo. Teoria dos Jogos com aplicações em economia, administração e ciências sociais. 3. ed. Rio de Janeiro: Elsevier, 2009.

35 "Foi possível também demonstrar que, em alguns casos, quando cada jogador escolhe racionalmente uma estratégia que seria a melhor resposta à estratégias dos demais, pode ocorrer que o resultado final para todos os jogadores seja insatisfatório e que, portanto, nem sempre a busca de cada indivíduo pelo melhor para si resulta no melhor para todos" FIANI, Ronaldo. Teoria dos Jogos com aplicações em economia, administração e ciências sociais. 3. ed. Rio de Janeiro: Elsevier, 2009. p. 36.

36 "As sociedades em pequena escala são diferentes. Muitos daqueles que são bem informados sobre a dificuldade de explicar a ação coletiva no bojo da teoria da escolha racional contentam-se em abrir exceções. A pequena escala alarga o campo de ação dos efeitos interpessoais. Todo o campo da psicologia localiza-se aqui, juntamente com as emoções irracionais. Quando a escala das relações é suficientemente pequena para ser pessoal qualquer coisa pode acontecer e a teoria da escolha racional reconhece os limites de seus domínios. Em conseqüência, parece não existir um problema teórico em relação ao altruísmo quando a organização social é muito pequena. Entretanto, um exame mais detido revela que isentar as sociedades de pequena escala da força da análise racional é algo que não resiste bem a uma crítica. Elas não podem ser mais isentas do que as organizações religiosas. Faz-se necessário ampliar os argumentos da escolha racional, de tal modo a abrir aquelas áreas interditas onde não se supõe que a teoria penetre. Então a teoria se desnuda. Ela enfrentará inelutavelmente dificuldades agudas que não podem ser escamoteadas tomando como referência a escala ou fatores religiosos, emocionais ou irracionais. Este passo é necessário para se confrontar o registro empírico inoportuno. Sabemos que os indivíduos submetem seus interesses particulares ao bem dos outros, que o comportamento altruísta pode ser observado, que os grupos exercem uma influência sobre o pensamento de seus membros e até mesmo desenvolvem estilos de pensamento distintos. Sabemos isso sem dispormos de uma teoria do comportamento que leve tal fato em conta" DOUGLAS, Mary. Como as instituições pensam. São Paulo: Universidade de São Paulo, 1998. p. 31.

${ }^{37}$ SOUSA, Jessé. Ralé brasileira: quem é e como vive. Belo Horizonte: UFMG, 2009. 
além de doses diárias de motivação para vencer as dificuldades de aprendizado e da árdua disciplina exigida pelas boas escolas, ao passo que as crianças pobres praticamente não têm nenhum estímulo ou mesmo condições básicas de alimentação, higiene, educação familiar etc. que as tornem competidoras com boas chances de sucesso. Esse modelo se reproduz também na vida universitária e, por conseguinte, na profissional ${ }^{38}$.

As pessoas não são geradas com as mesmas capacidades e chances de desenvolvimento na competição social contemporânea ${ }^{39}$. E, ainda, culturas de classe que se desenvolvem e se perenizam nas comunidades e regiões do Brasil praticamente determinam com boa dose probabilística as chances de vida e oportunidades de crescimento intelectual e social de modo indelével ${ }^{40}$. 0 que ocorre, na realidade, é a perpetuação de um modelo de desigualdade de oportunidades que vem sendo reforçado ao longo dos séculos, de uma péssima distribuição de renda, de uma educação pública de má qualidade e de políticas públicas que efetivamente não viabilizam a realização de direitos básicos e reforçam a ineficiência do Estado na administração pública, o que resulta no "salve-se quem puder". A resposta mais incisiva do leviatã é enviar seus aparelhos repressivos para controlar as massas e combater crimes numa cruzada sem fim.

A aplicação dos meios alternativos de solução de conflitos como opção à judicialização seria relevante ao próprio equilíbrio social, por meio de condições de escolhas que atendam aos interesses das partes pela aplicação da Teoria dos Jogos, de modo a que as partes cooperem ${ }^{41}$ entre si num jogo de soma não zero, assim como a própria negociação ${ }^{42}$ entre a administração

\footnotetext{
${ }^{38}$ SOUSA, Jessé. Ralé brasileira: quem é e como vive. Belo Horizonte: UFMG, 2009.

39 "Para a mentalidade liberal, o homo economicus, disciplinado, autocontrolado e calculador de seus próprios interesses de longo prazo é algo que já vem no DNA de todo ser humano. Nada mais longe da verdade. Os indivíduos e os grupos sociais aos quais ele pertence são "construídos" de modo muito distinto" SOUSA, Jessé. Ralé brasileira: quem é e como vive. Belo Horizonte: UFMG, 2009. p. 83.

${ }^{40}$ SOUSA, Jessé. Ralé brasileira: quem é e como vive. Belo Horizonte: UFMG, 2009.

41 "Destaque-se que a cooperação está diretamente ligada às informações disponíveis às duas partes: muito possivelmente uma das partes não cooperará fornecendo à outra parte informações prejudiciais a si. Por outro lado, a presença do mediador força, pelo menos, haver a possibilidade de um equilíbrio de Nash, já que pela própria presença de um terceiro neutro ao processo, as partes tenderão a encontrar um acordo mutuamente satisfatório do qual ambas não deverão se arrepender no futuro. A presença do mediador garante isso, porque as partes sentir-se-ão constrangidas em oferecer propostas irreais ou em permanecer em posições fixas de negociação, o que possibilita que a discussão focalize os interesseis reais das partes. A mediação é caracterizada, ainda, por outro fundamento que permite concluir pela possibilidade de o equilíbrio de Nash sempre existir nesta modalidade de resolução de conflitos: toda mediação é um jogo de soma não-zero" LEITE, Gisele. A teoria dos jogos e os métodos de resolução de conflitos no direito processual. Jornal Jurid, 2 ago. 2016. Disponível em: $<$ http://www.jornaljurid.com.br/colunas/gisele-leite/a-teoria-dos-jogos-e-os-metodos-de-resolucao-deconflitos-no-direito-processual>. Acesso em: 31 jul. 2017.

42 "De outro lado, a negociação fulcrada em interesse tem estrutura diferenciada. Pois em primeiro lugar, é jogo cooperativo. 0 objetivo da negociação fulcrada em interesses não é vencer o outro negociador, mas, antes, buscar que ambos os negociadores atinjam seus interesses mútuos. Ao mudar o foco da
} 
ISSN 1981-3694

(DOI): $10.5902 / 1981369425664$

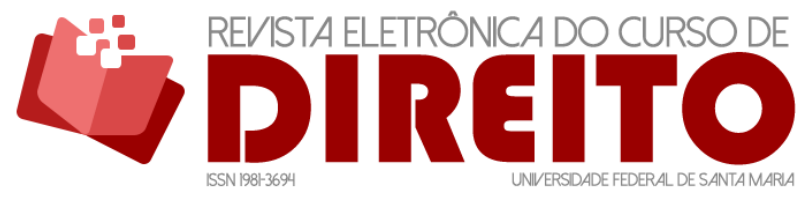

O SERVIÇO NOTARIAL E DE REGISTRO: DA JUDICIALIZAÇÃO À COMPOSICCÃO DE CONFLITOS COMO UM CONTRAPONTO À

BUROCRACIA ESTATAL

AFONSO SOARES OLIVEIRA SOBRINHO CLARINDO FERREIRA ARAUJO FILHO

pública e o administrado antes da execução fiscal. Se há uma dívida, em vez de se promover a princípio a execução de título judicial, que pode levar anos até que se encerre a demanda, pode a administração pública propor a mediação, reduzir juros da dívida e multas a fim de que a parte hipossuficiente possa pagar o quantum debeatur. Assim, o governo terá mais chance de receber os impostos devidos pelo contribuinte mediante o parcelamento da dívida, de modo que a adeque às suas reais condições financeiras e dentro de prazos que atendam ao seu orçamento, e, assim, todos podem sair ganhando, pois se economizam custas processuais, tempo e dinheiro, enquanto há menos burocracia na solução de controvérsias.

\section{SERVIÇO NOTARIAL E DE REGISTRO: A TRANSIÇÃO DA BUROCRACIA PÚBLICA COM VISTAS AO ACESSO À JUSTIÇA}

A judicialização assume o papel burocrático de tentar contornar as falhas do sistema e gerenciar crises. $E$ isso reforça a ideia de que os sistemas burocráticos atuam tão somente para manter tais mazelas, ampliando o fosso entre os afortunados e os pobres.

Conforme Jiménez, existe "uma tendência em converter os problemas políticos em problemas burocráticos"43. Dessa forma, o bode expiatório passaria a ser a burocracia e não a incapacidade política de responder adequadamente e de forma célere aos anseios da população. Ora, boa parte da morosidade existente no sistema jurídico pátrio tem como causa a utilização exagerada dos muitos procedimentos e recursos processuais que, não obstante sejam legal e legitimamente previstos, são em sua grande maioria utilizados como forma de postergar a emissão de sentenças, o que só prolonga o tempo do processo ${ }^{44}$. Esse excesso de ritos, ou seja,

negociação de posições para interesses, é possível atingir um conjunto de resultados melhores, se houver cooperação com a parte adversária, já que em muitos dos interesses podem ser compatíveis entre si, e, portanto, vir agregar valor à negociação. Outra característica da negociação baseada em interesses é a configuração desta como um jogo de soma não-zero. Sendo possível trazer elementos exteriores ao objeto de negociação, de forma a agregar valor à mesma" LEITE, Gisele. A teoria dos jogos e os métodos de resolução de conflitos no direito processual. Jornal Jurid, 2 ago. 2016. Disponível em: $<$ http://www.jornaljurid.com.br/colunas/gisele-leite/a-teoria-dos-jogos-e-os-metodos-de-resolucao-deconflitos-no-direito-processual>. Acesso em: 31 jul. 2017.

43 "la tendência es convertir los problemas políticos en problemas burocráticos". JIMÉNEZ, Alfredo Ramos. La construcción del orden democrático: burocracia, tecnocracia y meritocracia. Mérida, Venezuela: Centro de Investigações de Política Comparada, 2014. p. 93. Tradução nossa.

${ }^{44}$ SADEK, Maria Teresa (Org. ). 0 sistema de justiça. Rio de Janeiro: Centro Edelstein de Pesquisas Sociais, 2010;

SCAVONE JÚNIOR, Luiz Antônio. Modelos de peças no novo CPC. São Paulo: Forense Jurídica - Grupo Gen, 2016. 
esse crescente procedimentalismo ${ }^{45}$ nos leva a refletir sobre o verdadeiro problema da justiça, que não se reduz ao acesso à justiça, como pensam alguns, mas à realização pura e simples de direitos (o conseguir vencer o imbróglio dos labirintos procedimentais da justiça): "não é à toa que a Ministra Eliana Calmon chegou a afirmar que o difícil no Brasil não é o acesso à justiça, o difícil é conseguir sair da justiça". ${ }^{46}$

Para construir uma cultura de paz, ou cultura da paz, como preferem alguns, é preciso conhecer as gêneses da violência (física e emocional), bem como o conflito, tanto interior como o conflito que nasce do desacordo entre as nossas necessidades e as de nossos semelhantes ${ }^{47,48}$.

Nas últimas décadas, muitos movimentos provocaram influências nas reformulações dos sistemas judiciários, uma onda reformista que alterou estruturas antes consideradas pétreas em muitas nações de todos os continentes. Dentre estes, destaca-se a desjudicialização, aqui analisada sob uma perspectiva crítica; assim, desjudicializar em sentido amplo se aproxima da busca por um direito que atenda às necessidades da sociedade do século XXI. Portanto, soluções dentro e fora do judiciário com vistas à realização de um direito justo ${ }^{49}$, efetivo. Por sua vez, em sentido estrito significa desburocratizar procedimentos, abrir possibilidades de escolhas às partes quanto à melhor solução para suas demandas, interesses, e passa pela capacidade negocial das partes com paridade de armas às soluções de controvérsias, como utilização da

45 Para entender algumas das nuances deste fenômeno, ler RAWLS, John. Uma teoria da justiça. São Paulo: Martins Fontes, 2008. E também OLIVEIRA, Pablo Camarço. Teoria da Justiça de John Rawls tensão entre procedimentalismo puro universalismo e procedimentalismo perfeito contextualismo. Curitiba: Juruá, 2015.

${ }^{46}$ NALINI, José Renato. A rebelião da toga. Campinas: Millennium, 2008. p. 107.

47 Um conflito pode ser definido como a diferença entre dois objetivos que são buscados por parte de uma sociedade, ou seja, o conflito existe quando duas ou mais pessoas entram em desacordo porque as suas opiniões, desejos, valores e/ou necessidades são incompatíveis. Consequentemente, perante o conflito, as pessoas em geral assumem três tipos de atitudes: 1) ignoram o conflito; 2) respondem de forma violenta ao conflito; 3 ) lidam com o conflito de forma não violenta, por meio do diálogo/consenso. Com certeza as duas primeiras alternativas não são as melhores, mas quando se aprende a lidar com o conflito de forma não violenta, de forma justa e pacífica, essa é a melhor das opções para restaurar a paz. Portanto, para construir e encarar os conflitos de forma não violenta é preciso mudar atitudes, crenças e comportamentos (PELIZZOLI, Marcelo [Org.]. Cultura de paz: restauração e direitos. Recife: UFPE, 2010. p. 83).

${ }^{48}$ ROSENBERG, Marshall B. Comunicação não-violenta: técnicas para aprimorar relacionamentos pessoais e profissionais. São Paulo: Ágora, 2006.

${ }^{49}$ A ordem jurídica justa seria aquela que atende aos valores e princípios constitucionais e que permite o acesso à justiça por meio dos instrumentos democrático-participativos, desde uma justiça célere, com duração razoável do processo com vistas à efetivação do direito. Nesse diapasão, a desjudicialização ganha força, seja pela conciliação, mediação ou arbitragem como meios de composição de conflitos mais equânimes e com maior satisfação de interesses possível para os envolvidos. OLIVEIRA SOBRINHO, Afonso Soares de; ARAÚJO FILHO, Clarindo Ferreira. A crise do Estado e a desjudicialização: entre o imobilismo e a busca por uma ordem jurídica justa. Brasília: Conpedi, 2016. Disponível em: <http://www.conpedi.org.br/publicacoes/y0ii48h0/3z3f9fv8/PBVbx76BjS0doNz7.pdf>. Acesso em: 28 dez. 2016. 
mediação e da arbitragem. Os serviços notarial e registral podem prestar relevantes contribuições à comunidade, inclusive pela utilização da mediação extrajudicial com vistas à promoção de uma cultura de paz.

Destacamos, assim, no processo de desjudicialização com vistas ao acesso à justiça, a cláusula escalonada ${ }^{50}$, os tribunais multiportas ${ }^{51,52}$, ou, ainda, o movimento da delegação de serviços antes privativos do Estado, como no caso de notários e registradores, o movimento do neoconstitucionalismo ${ }^{53}$ etc.

50 "As cláusulas escalonadas são meios combinados e multietapas de resolução de controvérsias. Há
inúmeras possibilidades de combinações entre os meios, entretanto as mais utilizadas são as cláusulas
escalonadas med-arb e arb-med, estipulações contratuais que preveem fases sucessivas que contemplam
os mecanismos mediação e arbitragem para a solução de controvérsias. Por meio da cláusula med-arb, as
partes elegem submeter primeiramente o conflito à mediação, seguida da arbitragem, na hipótese de não
terem chegado ao acordo total acerca da controvérsia. Já na arb-med, as fases se invertem: a arbitragem
é inicialmente instituída e posteriormente suspensa para que a mediação aconteça. Caso as partes
cheguem ao acordo, o árbitro o homologa. Em caso contrário, a arbitragem é retomada" LEVY, Fernanda
Rocha Lourenço. Arbitragem, mediação e a cláusula escalonada. Carta Forense, 2 jun. 2014. Disponível
em: $\quad$ http:// /www.cartaforense.com.br/conteudo/entrevistas/arbitragem-mediacao-e-a-clausula-
escalonada/13774>. Acesso em: 27 dez. 2016 . ${ }^{51}$ Este movimento ocorreu originalmente na justiça norte-americana. ASPERTI, Maria Cecília de Araújo. Meios consensuais de resolução de disputas repetitivas: a conciliação, a mediação e os grandes litigantes do judiciário. 2014. Dissertação (Mestrado em Direito Processual)-Faculdade de Direito, Universidade de São Paulo, São Paulo, 2014. Disponível em: <http://www.teses.usp.br/teses/disponiveis/2/2137/tde-27012015-163101/>. Acesso em: 11 ago. 2016.

52 "O modelo idealizado por Frank Sander, denominado de Multidoor Courthouse System - Sistema das Múltiplas Portas, tinha como fulcro central oferecer soluções mais congruentes às peculiaridades de cada demanda, de forma mais efetiva, célere e de custeio razoável. Esse sistema consiste em disponibilizar vários mecanismos de solução de conflitos para os processos trazidos ao Judiciário. 0 conceito tem a premissa da noção de que há vantagens e desvantagens em cada caso específico ao usar um ou outro processo de resolução de disputas, sendo que a existência de várias possibilidades é a situação ideal" SALES, Lilia Maia de Morais; SOUZA, Mariana Almeida de. O Sistema de Múltiplas Portas e o judiciário brasileiro. Direitos Fundamentais \& Justiça, ano 5, n. 16, 2011. Disponível em: <http://www.dfj.inf.br/Arquivos/PDF_Livre/16_Dout_Nacional_7.pdf>. Acesso em: 27 dez. 2016.

53 "O marco histórico do novo direito constitucional, na Europa continental, foi o constitucionalismo do pós-guerra, especialmente na Alemanha e na Itália. No Brasil, foi a Constituição de 1988 e o processo de redemocratização que ela ajudou a protagonizar [...]. A principal referência no desenvolvimento do novo direito constitucional é a Lei Fundamental de Bonn (Constituição alemã), de 1949, e, especialmente, a criação do Tribunal Constitucional Federal, instalado em 1951 [...]. A segunda referência de destaque é a da Constituição da Itália, de 1947, e a subsequente instalação da Corte Constitucional, em 1956. Ao longo da década de 70, a redemocratização e a reconstitucionalização de Portugal (1976) e da Espanha (1978) agregaram valor e volume ao debate sobre o novo direito constitucional [...]. O marco filosófico do novo direito constitucional é o pós-positivismo. 0 debate acerca de sua caracterização situa-se na confluência das duas grandes correntes de pensamento que oferecem paradigmas opostos para o Direito: 0 jusnaturalismo e o positivismo. Opostos, mas, por vezes, singularmente complementares [...]. No plano teórico, três grandes transformações subverteram o conhecimento convencional relativamente à aplicação do direito constitucional: a) o reconhecimento de força normativa à Constituição; b) a expansão da jurisdição constitucional; c) o desenvolvimento de uma nova dogmática da interpretação constitucional" BARROSO, Luís Roberto. Neoconstitucionalismo e constitucionalização do direito: o triunfo tardio do direito constitucional no Brasil. Revista de Direito Administrativo, FGV, Rio de Janeiro, $\quad$ v. 240, abr./jun. $2005 . \quad$ Disponível em: 
ISSN 1981-3694

(DOI): $10.5902 / 1981369425664$

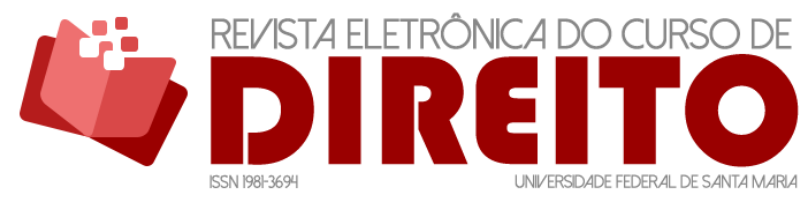

O SERVIÇO NOTARIAL E DE REGISTRO: DA JUDICIALIZAÇ̃̃O À COMPOSIÇÃO DE CONFLITOS COMO UM CONTRAPONTO Ä BUROCRACIA ESTATAL

AFONSO SOARES OLIVEIRA SOBRINHO CLARINDO FERREIRA ARAUJO FILHO

Esses ímpetos contribuíram para que as reformas tanto do Código Civil como do Código de Processo Civil brasileiros enfim se transformassem em realidade, num esforço que perdurou por quase duas décadas. No entanto, alguns desses avanços oneram ainda mais os cofres públicos e fortalecem a dependência da sociedade perante a burocracia judiciária ${ }^{54}$, como a resistência na cultura do conflito e da arrecadação da máquina judicial.

Para Cappelletti e Garth, por exemplo, os sistemas jurídicos atuais carecem de reformas urgentes, porque, a cada dia que passa, mais e mais setores da sociedade civil questionam sobre os elevados custos de transação desses sistemas e para quem ou para quais grupos, de fato, tais sistemas se encontram estruturados ${ }^{55}$.

Nesse sentido, destacam-se os notários e registradores, que, por sua vez, agora concursados para assumirem os cargos, podem administrar os cartórios de modo a responder mais rapidamente às necessidades e demandas impostas pelo mercado da publicitação, da segurança jurídica, do acesso à justiça etc.

Assim, nota-se a necessidade de garantia da prestação de um serviço com qualidade e eficiência para o usuário final, o que demanda significativa melhoria no tocante ao acesso à justiça, à publicização, à segurança jurídica etc., pois os serviços prestados por notários e registradores concursados, agora ampliados pelas novas legislações, possibilitam, por exemplo, a efetivação do divórcio por escritura extrajudicial, assim como a usucapião administrativa, e outros institutos distinguem-se daqueles prestados de forma burocrática pela via judiciária, que custa caro ao erário público, que é suprido pelos impostos pagos por toda a sociedade brasileira, mas deixa a desejar pela morosidade e pouca eficácia social.

A estrutura da Justiça necessita promover a justiça gratuita e de boa qualidade para todos os membros da sociedade civil, que são os verdadeiros financiadores do sistema, a exemplo do que ocorre, pelo menos no texto constitucional, quanto ao direito à saúde. 0 resultado pode ser visto facilmente quando se analisa o relatório do Conselho Nacional de

<http://bibliotecadigital.fgv.br/ojs/index.php/rda/article/view/43618/44695>. Acesso em: 2 ago. 2017. p. 2-6.

${ }^{54}$ Cf. ASPERTI, Maria Cecília de Araújo. Meios consensuais de resolução de disputas repetitivas: a conciliação, a mediação e os grandes litigantes do judiciário. 2014. Dissertação (Mestrado em Direito Processual)-Faculdade de Direito, Universidade de São Paulo, São Paulo, 2014. Disponível em: <http://www.teses.usp.br/teses/disponiveis/2/2137/tde-27012015-163101/>. Acesso em: 11 ago. 2016;

CHIUVITE JÚNIOR, Mario. Processo e justiça: uma reflexão à luz dos ideais éticos fundamentais no âmbito da pacificação dos conflitos judiciais. 2010. Tese (Doutorado em Filosofia e Teoria Geral do DireitoFaculdade de Direito, Universidade de São Paulo, São Paulo, 2010. Disponível em: <http://www.teses.usp.br/teses/disponiveis/2/2139/tde-27052010-102922/pt-br.php>. Acesso em: 15 set. 2016.

${ }^{55}$ CAPPELLETTI, Mauro; GARTH, Bryant. Acesso à justiça. Porto Alegre: Sérgio Antônio Fabris Editora, 2002. 
Justiça $^{56}$, que utiliza termos de contabilidade gerencial e administração financeira tipicamente usados por analistas financeiros, como, por exemplo, o conceito de taxa de retorno ${ }^{57}$. Ora, em que medida os serviços notariais e registrais agora delegados efetivamente conseguem realizar direitos constitucionalmente garantidos como, por exemplo, o acesso à justiça?

Os mecanismos extrajudiciais ampliados por meio das reformas do Código Civil, do Código de Processo Civil e de outras legislações hoje permitem que vários institutos antes compulsoriamente tutelados pelo Estado - divórcio, usucapião etc. - possam ser realizados por meio de escrituras lavradas extrajudicialmente nos cartórios. Procedimentos que antes se arrastavam por meses e até mesmo por anos nos meandros da burocracia despótica do judiciário, atualmente, são realizados de forma rápida e com segurança jurídica, e isso é, sem dúvida alguma, uma melhoria do acesso à justiça.

Um Estado moderno depende da administração pública e de toda uma gama de agentes públicos e de instituições privadas para suprir as necessidades da soberania e da organização da sociedade civil. Em outras palavras, depende visceralmente da burocracia, no sentido weberiano do termo, para arrecadar tributos, regulamentar atividades, prover bens $\mathrm{e}$ direitos constitucionalmente estabelecidos, realizar a divisão do trabalho etc. No entanto, ao realizar sucessivas regulamentações, algumas atividades nem sempre levam em conta os ideais da democracia, da justiça social e da participação de todos, pois como foi visto anteriormente, boa parte das desigualdades sociais não é combatida pelos representantes das elites conservadoras ${ }^{58}$.

\footnotetext{
${ }^{56}$ CONSELHO NACIONAL DE JUSTIÇA (CNJ). Justiça em número, 2015: ano-base 2014. Brasília: CNJ, 2015. Disponível em: <http://www.cnj.jus.br/programas-e-acoes/pj-justica-em-numeros>. Acesso em: 4 set. 2016.

${ }^{57}$ De acordo com Gitman, existem basicamente duas taxas de retorno que devem ser utilizadas para analisar o desempenho das empresas, a saber: 1) Taxa de Retorno sobre o Ativo Total (ROA): segundo o ROA, mede a eficiência global da administração na geração de lucros com seus ativos disponíveis. Quanto mais alta for essa taxa, melhor. ROA = (Lucro Líquido após o Imposto de Renda)/Ativo Total; 2) Taxa de Retorno sobre o Patrimônio Líquido (ROE): o ROE mede o retorno obtido sobre o investimento dos proprietários da empresa. Geralmente, quanto mais alta for essa taxa de retorno, melhor para os proprietários. ROE = (Lucro Líquido após o Imposto de Renda)/Patrimônio Líquido (GITMAN, Lawrence J. Princípios de administração financeira. 7. ed. São Paulo: Barbra, 2002). Para entender melhor o fenômeno da governança corporativa que hoje engloba tanto a burocracia pública como a privada, ler: GUIMARÃES, Feliciano de Sá. A autonomia burocrática das organizações financeiras internacionais: um estudo comparado entre o Banco Mundial e o Fundo Monetário Internacional. 2010. Tese (Doutorado em Ciência Política)-Faculdade de Filosofia, Letras e Ciências Humanas, Universidade de São Paulo, São Paulo, 2010. Disponível em: <http://www.teses.usp.br/teses/disponiveis/8/8131/tde-20102010110725/pt-br.php>. Acesso em: 14 set. 2016.

${ }^{58}$ Para entender melhor o fenômeno da homologia existente entre a burocracia pública e a privada, ler: CUNHA, Elemi Paço. Que fazer da burocracia de estado? Do indiferentismo às reciprocidades. Administração Pública e Gestão Social, Viçosa, v. 8, n. 1, p. 1-74, jan./mar. 2016. Disponível em: <http://www.apgs.ufv.br/index.php/apgs/article/view/922/456>. Acesso em: 22 set. 2016.
} 
As deturpações causadas pela burocracia não são uma exclusividade do modelo brasileiro. A União Europeia, formada por países que são considerados como genitores do pensamento ocidental moderno, também continua tendo problemas. O continente europeu, agora sob a égide da burocracia transnacional da União Europeia, muito provavelmente, é a maior vítima da perpetuação de uma burocracia que pode ser classificada como despótica ${ }^{59}$, como bem descrevem Fernando C. Prestes Motta, ao analisar os modelos da burocracia vigente nas organizações contemporâneas, e Tony Judt, ao discorrer sobre a história europeia no pósguerra $^{60}$.

Para Max Weber ${ }^{61}$, a realização de direitos pode ser muito prejudicada pela administração pública, porque esta atua como braço de poder do governo, e, em diversas ocasiões, as normas que deveriam servir de garantias existem apenas de uma maneira formal, ou seja, como uma espécie de regulamento a serviço da coerção ou mera figura decorativa, pois na prática não se realiza.

\footnotetext{
${ }^{59} \mathrm{Na}$ visão de Motta, a burocracia evoluiu para formas despóticas e hoje permeia tanto a estrutura estatal como as empresas de grande porte, os sindicatos, escolas, partidos etc. Daí a expressão "burocracia despótica", e leciona: “[...] Na realidade, não existe país em que a burocracia estatal não tenha assumido aspecto semelhante ao de uma empresa de grande porte, seja pela sua atuação produtiva, paraprodutiva ou reguladora, seja por suas funções repressivas e ideologias cada vez mais fortes. De resto, para determinados efeitos e em determinado nível de abstração, chega-se próximo ao preciosismo quando se tenta estabelecer diferenças de essência entre a burocracia estatal e a burocracia dos grandes grupos econômicos. Até mesmo a preocupação em delinear traços das burocracias educacionais, sindicais, partidárias, etc. só faz sentido a partir de uma compreensão mais aprofundada de um fenômeno mais geral, a saber, o fenômeno burocrático [...] a burocracia é um grupo que tende a fazer prevalecer um certo modo de organização, que se desenvolve em condições determinadas, que se amplia devido a um certo estado da economia e da técnica, mas que somente é o que é em sua essência, em virtude de uma atividade social. Dois aspectos dessa conceituação merecem destaque especial. Em primeiro lugar, a questão da atividade social que se refere à intenção dos burocratas de se constituírem um grupo à parte, de participarem de um sistema de poder coletivo, que se define em oposição à ausência de poder dos dominados, bem como de se organizarem num sistema de mando e subordinação que estabelece diferenças materiais e de prestígio entre os membros do grupo. Outra questão que merece destaque refere-se ao desenvolvimento da burocracia, especialmente às condições históricas desse desenvolvimento, sem as quais o fenômeno fica totalmente despido de sentido. 0 que se torna difícil de entender é o desenvolvimento por toda parte de hierarquias complexas de administradores profissionais, que nas suas funções de restringir ou de auxiliar a ação de indivíduos de segmentos sociais ou mesmo de toda a sociedade acabam por torná-los objetos dependentes e passivos de seu arbítrio. Não parece ser outro em realidade o traço uniformizador das chamadas democracias liberais e das formas diversas de despotismos totalitários que temos conhecido. A burocracia inserida no centro desses sistemas é em si um sistema, que não varia em essência de caso para caso." (MOTTA, Fernando C. Prestes. Organização e poder: empresa, Estado e escola. São Paulo: Atlas, 1986. p. 37-38).

${ }^{60}$ Tony Judt faz uma rica explanação sobre clientelismo, corrupção e obtenção de vantagens pessoais por parte da nova burocracia financiada pela União Europeia. Para tanto, ler: JUDT, Tony. Pós-guerra: uma história da Europa desde 1945. Rio de Janeiro: Objetiva, 2008.

${ }^{61}$ WEBER, Max. Economia e sociedade: fundamentos da sociologia compreensiva. Brasília: Universidade de Brasília; São Paulo: Imprensa Oficial do Estado de São Paulo, 1999.
} 
ISSN 1981-3694

(DOI): $10.5902 / 1981369425664$

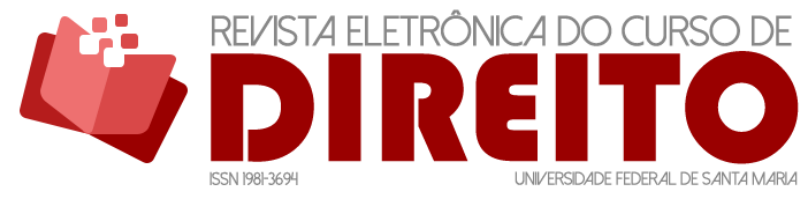

O SERVIÇO NOTARIAL E DE REGISTRO: DA JUDICIALIZAÇ̃̃O À COMPOSIÇÃO DE CONFLITOS COMO UM CONTRAPONTO Ä

BUROCRACIA ESTATAL

AFONSO SOARES OLIVEIRA SOBRINHO CLARINDO FERREIRA ARAUJO FILHO

Percebe-se, ainda segundo a visão de $A l m e i d a^{62}$, que realizou estudos voltados para o campo político da justiça, que sobrevive em nossos dias uma arena em que os interesses das elites jurídicas brasileiras ganham força para influenciar a edição de códigos legais capazes de manter o status quo discricionário e reducionista da burocracia estatal. Contudo, as lutas pelo poder no seio da burocracia estatal nem sempre visam melhorar a vida dos cidadãos e das empresas, que por meio de seus impostos financiam toda a estrutura estatal, no que restam indagações sobre o futuro do Estado e o respeito aos princípios constitucionais ${ }^{63}$.

Assim, a desjudicialização ganha força, especialmente, quanto às possibilidades de escolhas com vistas a um direito justo. Nesse diapasão, a autonomia das partes no processo e na via extrajudicial é norteado pelos meios adequados à solução de controvérsias.

Os serviços notariais e de registro se coadunam com a lógica do uso dos meios extrajudiciais na solução de conflitos, cuja delegação de tarefas produziu eficiência, acessibilidade, presteza e qualidade dos serviços prestados por profissionais qualificados e prontos a responderem às demandas da população, em inúmeras localidades em que não existem outras instituições judiciárias do Estado ou mesmo profissionais do direito que atuam no mercado. Na maioria das situações do dia a dia, notários e registradores prestam esclarecimentos e tiram dúvidas na elaboração de contratos, procurações, escrituras etc., suprindo a falta de entes públicos capazes de atender a tais demandas ${ }^{64}$.

\footnotetext{
${ }^{62}$ ALMEIDA, Frederico Normanha Ribeiro de. A nobreza togada: as elites jurídicas e a política da Justiça no Brasil. 2010. Tese (Doutorado em Ciência Política)-Faculdade de Filosofia, Letras e Ciências Humanas, Universidade de São Paulo, São Paulo, 2010. Disponível em: <http://www.teses.usp.br/teses/disponiveis/8/8131/tde-08102010-143600/pt-br.php>. Acesso em: 14 set. 2016.

63 “[...] A resposta à indagação sobre se o futuro do nosso Estado é uma questão de poder ou um problema jurídico depende da preservação e do fortalecimento da força normativa da Constituição, bem como de seu pressuposto fundamental, a vontade de Constituição. Essa tarefa foi confiada a todos nós" HESSE, Konrad. A força normativa da constituição. Porto Alegre: Sergio Antônio Fabris Editora, 1991. p. 15.

${ }^{64}$ Cf. BRANDELLI, Leonardo. Teoria geral do direito notarial. São Paulo: Saraiva, 2011;

LOUREIRO, Luiz Guilherme. Registros públicos: teoria e prática. Rio de Janeiro: Forense; São Paulo: Método, 2010;

LOUREIRO FILHO, Lair da Silva; LOUREIRO, Claudia Regina de Oliveira Magalhães da. Notas e registros públicos. São Paulo: Saraiva, 2012.
} 


\section{CONCLUSÃO}

O fenômeno da burocracia desperta o fascínio e sentimentos díspares, como a afinidade humana pelo racionalismo ou como a repulsa pelo poder despótico dos burocratas e governantes. Essa supervalorização da burocracia desperta o imaginário para formas imediatas, efetivas e que muitas vezes nos causam frustrações e revoltas mediante a força do leviatã em impor leis que nos fragiliza e restringe as liberdades. A burocracia estatal que nos domina e que controla toda a vida pública e privada. Assim, os sistemas burocráticos mantêm e ampliam o fosso entre os afortunados e os pobres, como parte de um jogo em que uma parte abastada se beneficia em detrimento da maioria que não tem acesso às mesmas oportunidades. A estrutura do sistema judiciário brasileiro precisa ser repensada de modo a tornar a justiça acessível, inclusive pela utilização da Teoria dos Jogos a partir da cooperação com vistas a resultados de soma não zero, por meio da mediação de conflitos, com o intuito de obter maior aproximação entre o Estado e os cidadãos, que são os verdadeiros financiadores da máquina pública. Nesse diapasão, o notariado brasileiro pode servir como um importante instrumento de acesso à justiça, como já tem feito naquilo que a lei the autorizou a realizar (divórcio extrajudicial, usucapião administrativa etc.), especialmente por ser aquele mais próximo da comunidade, aprimorando sua atuação na solução de conflitos por meio da autonomia privada e da promoção de uma cultura de paz.

\section{REFERÊNCIAS}

ALMEIDA, Frederico Normanha Ribeiro de. A nobreza togada: as elites jurídicas e a política da Justiça no Brasil. 2010. Tese (Doutorado em Ciência Política)-Faculdade de Filosofia, Letras e Ciências Humanas, Universidade de São Paulo, São Paulo, 2010. Disponível em:

<http: //www.teses.usp.br/teses/disponiveis/8/8131/tde-08102010-143600/pt-br.php>. Acesso em: 14 set. 2016.

ARISTÓTELES. A política. Tradução de Nestor Silveira Chaves. Bauru: Edipro, 1995. Série Clássicos.

ASPERTI, Maria Cecília de Araújo. Meios consensuais de resolução de disputas repetitivas: a conciliação, a mediação e os grandes litigantes do judiciário. 2014. Dissertação (Mestrado em Direito Processual)-Faculdade de Direito, Universidade de São Paulo, São Paulo, 2014. 
Disponível em: <http://www.teses.usp.br/teses/disponiveis/2/2137/tde-27012015-163101/>. Acesso em: 11 ago. 2016.

BARROSO, Luís Roberto. Neoconstitucionalismo e constitucionalização do direito: o triunfo tardio do direito constitucional no Brasil. Revista de Direito Administrativo, FGV, Rio de Janeiro, v. 240, abr./jun. 2005. Disponível em:

<http://bibliotecadigital.fgv.br/ojs/index.php/rda/article/view/43618/44695>. Acesso em: 2 ago. 2017.

BRANDELLI, Leonardo. Teoria geral do direito notarial. São Paulo: Saraiva, 2011.

CAPPELLETTI, Mauro; GARTH, Bryant. Acesso à justiça. Porto Alegre: Sérgio Antônio Fabris Editora, 2002.

CHASIN, Milene. Política, limite e mediania em Aristóteles. 2007. Tese (Doutorado em História Social) - Faculdade de Filosofia, Letras e Ciências Humanas, Universidade de São Paulo, São Paulo, 2007. Disponível em: <http://www.teses.usp.br/teses/disponiveis/8/8138/tde-04122007110142/pt-br.php>. Acesso em: 15 set. 2016.

CHAUÍ, Marilena. Brasil: mito fundador e sociedade autoritária. São Paulo: Perseu Abramo, 2000.

CHIUVITE JÚNIOR, Mario. Processo e justiça: uma reflexão à luz dos ideais éticos fundamentais no âmbito da pacificação dos conflitos judiciais. 2010. Tese (Doutorado em Filosofia e Teoria Geral do Direito-Faculdade de Direito, Universidade de São Paulo, São Paulo, 2010. Disponível em: <http://www.teses.usp.br/teses/disponiveis/2/2139/tde-27052010-102922/pt-br.php>. Acesso em: 15 set. 2016.

CONSELHO NACIONAL DE JUSTIÇA (CNJ). Justiça em número, 2015: ano-base 2014. Brasília: CNJ, 2015. Disponível em: <http://www.cnj.jus.br/programas-e-acoes/pj-justica-em-numeros>. Acesso em: 4 set. 2016.

COSTA, Luciana da Silva. A revisitação do princípio da separação de poderes: dialogicidade e tensão como elementos conformadores da identidade constitucional brasileira. 2014. Tese (Doutorado em Direito do Estado) - Faculdade de Direito, Universidade de São Paulo, São Paulo, 2014. Disponível em: <http://www.teses.usp.br/teses/disponiveis/2/2134/tde-21012015091338/pt-br.php>. Acesso em: 15 set. 2015.

CUNHA, Elemi Paço. Que fazer da burocracia de estado? Do indiferentismo às reciprocidades. Administração Pública e Gestão Social, Viçosa, v. 8, n. 1, jan./mar. 2016. Disponível em: <http://www.apgs.ufv.br/index.php/apgs/article/view/922/456>. Acesso em: 22 set. 2016.

DAMIANI, Gerson Denis Silvestre Duarte. Teoria dos jogos e relações internacionais: estratégias da governança mercantil global. Uma análise da convenção das Nações Unidas para os contratos de compra e venda internacional de mercadorias à luz de sua vinculação ao Brasil. 2014. Tese (Doutorado em Relações Internacionais) - Instituto de Relações Internacionais, Universidade de São Paulo, São Paulo, 2014. Disponível em:

<http://www.teses.usp.br/teses/disponiveis/101/101131/tde-08102014-171811/pt-br.php>. Acesso em: 15 set. 2016. 
ISSN 1981-3694

(DOI): $10.5902 / 1981369425664$

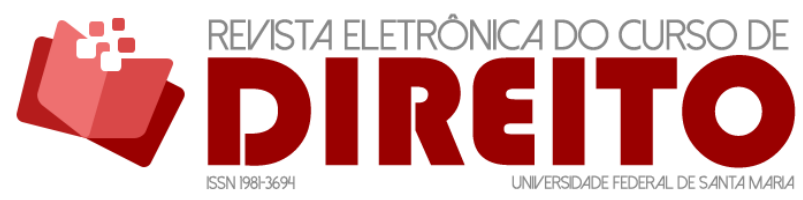

O SERVIÇO NOTARIAL E DE REGISTRO: DA JUDICIALIZAÇÃO À COMPOSIÇÃO DE CONFLITOS COMO UM CONTRAPONTO À BUROCRACIA ESTATAL

AFONSO SOARES OLIVEIRA SOBRINHO CLARINDO FERREIRA ARAUJO FILHO

DOUGLAS, Mary. Como as instituições pensam. São Paulo: Universidade de São Paulo, 1998.

FAORO, Raymundo. Os donos do poder: formação do patronato político brasileiro. 3. ed. São Paulo: Globo, 2001.

FERNANDES, Florestan. Sociedade de classes e subdesenvolvimento. 5. ed. São Paulo: Global, 2008.

FIANI, Ronaldo. Teoria dos Jogos com aplicações em economia, administração e ciências sociais. 3. ed. Rio de Janeiro: Elsevier, 2009.

GITMAN, Lawrence J. Princípios de administração financeira. 7. ed. São Paulo: Barbra, 2002.

GUIMARÃES, Feliciano de Sá. A autonomia burocrática das organizações financeiras

internacionais: um estudo comparado entre o Banco Mundial e o Fundo Monetário Internacional. 2010. Tese (Doutorado em Ciência Política)-Faculdade de Filosofia, Letras e Ciências Humanas, Universidade de São Paulo, São Paulo, 2010. Disponível em:

<http://www.teses.usp.br/teses/disponiveis/8/8131/tde-20102010-110725/pt-br.php>. Acesso em: 14 set. 2016.

HESSE, Konrad. A força normativa da constituição. Porto Alegre: Sergio Antônio Fabris Editora, 1991.

JIMÉNEZ, Alfredo Ramos. La construcción del orden democrático: burocracia, tecnocracia y meritocracia. Mérida, Venezuela: Centro de Investigações de Política Comparada, 2014.

JUDT, Tony. Pós-guerra: uma história da Europa desde 1945. Rio de Janeiro: Objetiva, 2008.

JUDT, Tony. Um tratado sobre os nossos atuais descontentamentos. Lisboa: Edições 70, 2012.

LEITE, Gisele. A teoria dos jogos e os métodos de resolução de conflitos no direito processual. Jornal Jurid, 2 ago. 2016. Disponível em: <http://www.jornaljurid.com.br/colunas/giseleleite/a-teoria-dos-jogos-e-os-metodos-de-resolucao-de-conflitos-no-direito-processual>. Acesso em: 31 jul. 2017.

LEVY, Fernanda Rocha Lourenço. Arbitragem, mediação e a cláusula escalonada. Carta Forense, 2 jun. 2014. Disponível em:

<http://www.cartaforense.com.br/conteudo/entrevistas/arbitragem-mediacao-e-a-clausulaescalonada/13774>. Acesso em: 27 dez. 2016.

LOUREIRO FILHO, Lair da Silva; LOUREIRO, Claudia Regina de Oliveira Magalhães da. Notas e registros públicos. São Paulo: Saraiva, 2012.

LOUREIRO, Luiz Guilherme. Registros públicos: teoria e prática. Rio de Janeiro: Forense; São Paulo: Método, 2010.

MOTTA, Fernando C. Prestes. Organização e poder: empresa, Estado e escola. São Paulo: Atlas, 1986. 
NALINI, José Renato. A rebelião da toga. Campinas: Millennium, 2008.

OLIVEIRA, Pablo Camarço. Teoria da Justiça de John Rawls: tensão entre procedimentalismo puro universalismo e procedimentalismo perfeito contextualismo. Curitiba: Juruá, 2015.

OLIVEIRA SOBRINHO, Afonso Soares de; ARAÚJO FILHO, Clarindo Ferreira. A crise do Estado e a desjudicialização: entre o imobilismo e a busca por uma ordem jurídica justa. Brasília: Conpedi, 2016. Disponível em:

<http://www.conpedi.org.br/publicacoes/y0ii48h0/3z3f9fv8/PBVbx76BjSOdoNz7.pdf>. Acesso em: 28 dez. 2016.

PELIZZOLI, Marcelo (Org.). Cultura de paz: restauração e direitos. Recife: UFPE, 2010.

RAMOS, Alberto Guerreiro. A redução sociológica. 3. ed. Rio de Janeiro: UFRJ, 1996.

RAWLS, John. Uma teoria da justiça. São Paulo: Martins Fontes, 2008.

ROSENBERG, Marshall B. Comunicação não-violenta: técnicas para aprimorar relacionamentos pessoais e profissionais. São Paulo: Ágora, 2006.

SADEK, Maria Teresa (Org.). O sistema de justiça. Rio de Janeiro: Centro Edelstein de Pesquisas Sociais, 2010.

SALES, Lilia Maia de Morais; SOUZA, Mariana Almeida de. O Sistema de Múltiplas Portas e o judiciário brasileiro. Direitos Fundamentais \& Justiça, ano 5, n. 16, 2011. Disponível em: <http://www.dfj.inf.br/Arquivos/PDF_Livre/16_Dout_Nacional_7.pdf>. Acesso em: 27 dez. 2016.

SCAVONE JÚNIOR, Luiz Antônio. Modelos de peças no novo CPC. São Paulo: Forense Jurídica Grupo Gen, 2016.

SOUSA, Jessé. A tolice da inteligência brasileira: ou como o país se deixa manipular pela elite. São Paulo: LeYa, 2015.

SOUSA, Jessé. Ralé brasileira: quem é e como vive. Belo Horizonte: UFMG, 2009.

TALEB, Nassim Nicholas. Antifrágil. Rio de Janeiro: Best Business, 2014.

TOCQUEVILLE, Alexis de. A democracia na América: leis e costumes de certas leis e certos costumes políticos que foram naturalmente sugeridos aos americanos por seu estado social democrático. 2. ed. São Paulo: Martins Fontes, 2005.

TRAGTENBERG, Maurício. A falência da política. São Paulo: Unesp, 2009.

VALLE, Vanice Regina Lírio do (Org.). Ativismo jurisdicional e o Supremo Tribunal Federal: Laboratório de Análise Jurisprudencial do STF. Curitiba: Juruá, 2009. 
ISSN 1981-3694

(DOI): $10.5902 / 1981369425664$

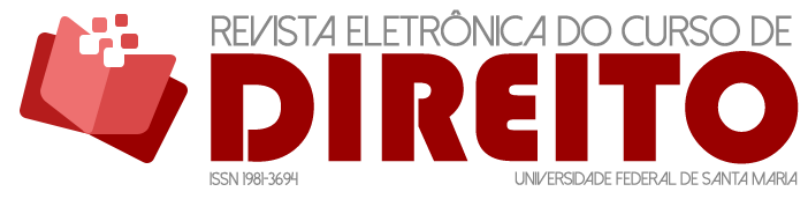

O SERVIÇO NOTARIAL E DE REGISTRO: DA JUDICIALIZAÇÃO À COMPOSIÇÃO DE CONFLITOS COMO UM CONTRAPONTO À

BUROCRACIA ESTATAL

AFONSO SOARES OLIVEIRA SOBRINHO CLARINDO FERREIRA ARAUJO FILHO

VASCONCELOS, Flávio Carvalho de. Racionalidade, autoridade e burocracia: as bases da definição de um tipo organizacional pós-burocrático. Revista de Administração Pública, Rio de Janeiro, v. 38, n. 2, p. 201-202, mar./abr. 2004.

WEBER, Max. Economia e sociedade: fundamentos da sociologia compreensiva. Brasília: Universidade de Brasília; São Paulo: Imprensa Oficial do Estado de São Paulo, 1999.

ZALUAR, Alba. A máquina e a revolta: as organizações populares e o significado da pobreza. 2. ed. São Paulo: Brasiliense, 1994.

\section{COMO FAZER A REFERÊNCIA DO ARTIGO (ABNT):}

OLIVEIRA SOBRINHO, Afonso Soares; ARAUJO FILHO, Clarindo Ferreira. O serviço notarial e de registro: da judicialização à composição de conflitos como um contraponto à burocracia estatal. Revista Eletrônica do Curso de Direito da UFSM, Santa Maria, RS, v. 12, n. 3, p. 790-815, dez. 2017. ISSN 1981-3694. Disponível em: <https://periodicos.ufsm.br/revistadireito/article/view/25664>. Acesso em: dia mês. ano. doi: http://dx.doi.org/10.5902/1981369425664. 